\title{
PENINGKATAN KETERAMPILAN BERPIKIR KRITIS DAN SIKAP KEMANDIRIAN BELAJAR MENGGUNAKAN MODEL PROBLEM BASED LEARNING PADA TEMA 7 DI KELAS V MIM 01 SAMBONG
}

\author{
Rois Triwibowo1, Badarudin², Aji Heru Muslim³ \\ ${ }^{123}$ Universitas Muhammadiyah Purwokerto \\ 1roistw215@gmail.com, 2badarudinbdg@gmail.com, 3ajiheru_muslim@yahoo.com
}

\begin{abstract}
This study aims to improve critical thinking skills and independent learning of students through problem based learning models in class $V$. The method used in this research is classroom action research. PTK is carried out for 2 cycles, each cycle consisting of 2 learning meetings with 1 meeting one learning implementation plan. The research procedure consists of several stages, namely the planning, action, observation and reflection. The research subjects were class V MIM 01 Sambong with 22 students consisting of 8 male students and 14 female students. This research data collection tool uses a critical thinking skills test, learning independence attitude questionnaire, student activity observation sheet and teacher activity observation sheet. The results of increasing critical thinking skills and students' learning independence can be seen at each stage of the cycle. The results of this CAR show that PBL models can improve critical thinking skills and learning independence in class V MIM 01 Sambong. Students show each cycle. Cycle 1 gets an average of 3.04 while cycle 2 gets an average of 3.74 with good criteria meanwhile in independent learning, cycle 1 gets average of 3,2 in the other hand cycle 2 gets average of 3,67 with good criteria.
\end{abstract}

Keywords: Critical Thinking, Independent Learning, Problem Based Learning

\begin{abstract}
ABSTRAK
Penelitian ini memiliki tujuan meningkatkan Keterampilan berpikir kritis dan kemandirian belajar pserta dididk melalui model problem based learning di kelas $\mathrm{V}$. Metode penelitian ini menggunakan penelitian tindakan kelas. PTK tersebut dilakukan selama 2 siklus, setiap siklus terdiri dari 2 pertemuan pembelajaran dengan 1 pertemuan satu rencana pelaksanaan pembelajaran. prosedur penelitian terdiri dari beberapa tahapan yaitu tahap perencanaan (planning), tindakan (action), observasi (observation) dan refleksi (reflection). Subjek penelitian yaitu kelas V MIM 01 Sambong berjumlah 22 peserta didik terdiri dari 8 siswa laki-laki dan 14 siswa perempuan. Alat pengumpulan data penelitian ini menggunakan tes keterampilan berpikir kritis, angket sikap kemandirian belajar, lembar observasi aktivitas peserta didik dan lembar observasi aktivitas guru. Hasil meningkatnya keterampilan berpikir kritis dan kemandirian belajar peserta didik dapat dilihat disetiap tahapan siklus. Hasil PTK ini menunjukanbahwa model PBL dapat meningkatkan keterampilan berpikir kritis dan kemandirian belajar di kelas V MIM 01 Sambong. Peserta didik menunjukan setiap siklus. Pada siklus 1 mendapatkan rata-rata 3.04 sedangkan siklus 2 mendapatkan rata-rata 3.74 dengan kriteria baik dan pada kemandirian
\end{abstract}


belajar mendapatkan rata-rata 3,2 sedangkan siklus 2 mendapatkan 3,67 dengan kriteria baik.

Kata Kunci : Berpikir Kritis, Kemandirian Belajar, Problem Based Learning

\section{A. Pendahuluan}

Pembelajaran abad 21 dituntut berbasis teknologi untuk meyeimbangkan tuntutan zaman era milenia dengan tujuan, nantinya peserta didik terbiasa dengan kecakapan hidup. Abad 21 yang dikenal semua orang sebagai abad pengetahuan yang merupakan landasan utama untuk berbagai aspek kehidupan. Paradigma pembelajaran abad 21 menekankan kemampuan siswa untuk berpikir kritis, mampu menghubungkan ilmu dengan dunia nyata, menguasai teknologi informasi, berkomunikasi dan berkolaborasi. Pencapaian keterampilan tersebut dapat dicapai dengan penerapan metode pembelajaran yang sesuai dari sisi penguasaan materi dan keterampilan. Greenstein (Sugiyarti, 2018:440) menyatakan bahwa siswa yang hidup pada abad 21 harus menguasai keilmuan, berketerampilan metakognitif, mampu berpikir kritis dan kreatif, serta bias berkomunikasi atau berkolaborasi yang efektif, keadaan ini menggambarkan adanya kesenjangan antara harapan dan kenyataan.

Pembelajaran tematik terpadu menekankan pada keterlibatan peserta didik secara aktif dalam proses pembelajaran untuk mengembangkan keterampilan berpikir peserta didik. Salah satu keterampilan berpikir yang perlu dikembangkan di sekolah dasar yaitu ketrampilan berpikir kritis. Ketrampilan berpikir kritis merupakan salah satu komponen abad ke-21 dan ketrampilan yang diperlukan peserta didik untuk memberikan pemahaman. Adyan (Indriyani, 2019: 29) yang menjelaskan bahwa keterampilan berpikir kritis dapat dikatakan sebagai keterampilan tingkat tinggi yang dapat membuat siswa melakukan analisis dengan cara menemukan fakta yang terjadi dan mampu memberikan argumen atau pendapat serta dapat mengambil keputusan yang tepat. Keterampilan berpikir kritis peserta didik tidak dapat tumbuh sendiri namun perlu dilatih secara rutin selama proses pembelajaran. 
Selain faktor keterampilan berpikir kritis, faktor kemandirian belajar juga diduga mempunyai pengaruh yang cukup penting dalam pencapaian hasil belajar siswa. Menurut Desmita (Suid, 2017: 72) kemandirian merupakan kemampuan untuk mengendalikan dan mengatur pikiran, perasaan dan tindakan sendiri secara bebas serta berusaha sendiri untuk mengatasi perasaan-perasaan malu dan keragu-raguan.

Berdasarkan hasil pengamatan secara langsung maupun tidak langsung terhadap proses pembelajaran yang berlangsung di MIM 01 Sambong, Kecamatan Punggelan, Kabupaten Banjarnegara khususnya dalam pembelajaran, pembelajaran ini dirasakan sebagian besar peserta didik kurang memiliki daya tarik untuk dipelajari. Sehingga dalam pelaksanaan pembelajarannya tidak berjalan sebagaimana mestinya dan peserta didik cenderung tidak fokus terhadap pembelajaran. Peserta didik dalam belajar cenderung merasa bosan, kurang tertarik, bahkan monoton atau berjalan seperti harihari biasa sebelumnya. Pembelajaran masih berpusat pada guru, proses pembelajaran masih berpusat mentransfer pengetahuan sehingga peserta didik kurang dihadapkan oleh permasalahan. Guna menyiasati pembelajaran ini diperlukan kegiatan pembelajaran yang merangsang peserta didik menjadi kritis dan mandiri dalam pembelajaran. Peran guru bukan lagi pemberi informasi tetapi sebagai fasilitator dan organisator. Guru dalam melaksanakan pengelolaan pembelajaran hendaknya dilakukan dengan sungguh-sungguh melalui perencanaan yang matang, memanfaatkan seluruh sumber daya yang ada serta memperhatikan taraf perkembangan intelektual dan perkembangan psikologi belajar peserta didik. Guru yang demikian akan dapat menghasilkan kualitas pembelajaran yang lebih tinggi dibandingkan dengan guru yang dalam pengelolaan pembelajarannya dilakukan seadanya tanpa mempertimbangkan berbagai faktor yang bisa mempengaruhi keberhasilan proses pembelajaran. Dalam pembelajaran peserta didik dididik dan diarahkan agar dapat menemukan pengetahuan yang akan dipelajari secara tidak langsung. Dengan kata lain, tidak serta merta 
siswa diberi pengetahuan tentang fakta-fakta atau meteri pelajaran secara langsung, sehingga guru memberikan kesempatan kepada peserta didik untuk "merasakan". Penelitian yang sudah dilakukan dengan menggunakan PBL yaitu oleh Susilowati, (2018) yang berjudul Pengruh PBL Terhadap Kemandirian Belajar Siswa SD. Sebelum menerapkan model pembelajaran problem based learning siswa yang tuntas hanya $48 \%$. Sedangkan setelah menerapkan model PBL meningkat menjadi $86,96 \%$. Sedangkan penelitian yang dilakukan Nugraha (2018) yang berjudul "Peningkatan Keterampilan Berpikir Kritis dan Penguasaan Konsep IPA Siswa SD Dengan Menggunakan Model PBL. Dari hasil penelitian yang dilakukan, didapatkan hasil peningkatan kemampuan berpikir kritis setelah pembelajaran dengan rata-rata peningkatan 30,70 sementara untuk hasil tes penguasaan konsep terjadi peningkatan dengan rata-rata 32,17 .

Bedasarkan latar belakang masalah di atas peneliti berkolaborasi bersama guru melakukan penelitian bejudul "Peningkatan Keterampilan
Betrpikir Kritis dan Sikap Kemandirian Belajar menggunakan model problem based learning pada tema 7 di kelas $V$ MIM 01 Sambong". Penelitian ini bertujuan unruk meningkatkan keterampilan berpikir kritis dan kemandirian belajar peserta didik.

\section{B. Metode Penelitian}

Jenis penelitian pada penelitian ini yaitu Penelitian Tindakan Kelas (PTK). PTK adalah penelitian yang berorientasi untuk memperbaiki baik proses dan hasil untuk memecahkan masalah yang ada dalam pembelarajan di kelas. Arikunto (2010: 2) menjelaskan PTK merupakan suatu tindakan perbaikan untuk menyelesaikan masalah melaluin suatu perbuatan nyata, bukan hanya mencermati fenomena tertentu kemudian mendeskripsikan apa yang terjadi dengan fenomena yang bersangkutan.

PTK ini dilakukan di kelas $\mathrm{V}$ MIM 01 Sambong, Kecamatan Punggelan Kabupaten Banjarnegara. Subyek penelitian ini merupakan peserta didik kelas $\mathrm{V}$ sejumlah 22 peserta didik yang terdiri dari 8 lakilaki dan 14 perempuan. Desain penelitian yang digunakan adalah model Kemmis dan Mc. Taggart terdiri 
dari empat tahapan penelitian yaitu tahap perencanaan (planning), tindakan (action), observasi (observation), dan refleksi (reflection). Penelitian ini menggunakan instrumen yaitu lembar observasi kegiatan aktivitas guru, lembar observasi kegiatan aktivtias peserta didik, kisi-kisi soal kemampuan berpikiri kritis, lembar tes kemampuan berpikir kritis, lembar observasi kemandirian belajar da angket kemandirian belajar. Teknik

\begin{tabular}{cl}
\hline No & \multicolumn{1}{c}{ Indikator } \\
\hline 1. & Memberikan penjelasan sederhana \\
\hline 2. & Membangun keterampilan dasar \\
\hline 3. & Membuat inverensi / menyimpulkan \\
\hline 4. & Memberikan penjelasan lebih lanjut \\
\hline 5. & Mengatur strategi dan taktik \\
\hline
\end{tabular}
pengumpulan data yaitu melalui teknik tes dan teknik non tes. Teknik tes menggunakan soal uraian yang diberikan pada peserta didik sedangkan teknik non tes berupa obervasi dan dokumentasi saat penelitian. Analisis data yang digunakan pada penelitian untuk mendapatkan data yang diperoleh, baik data penelitian melalui teknik tes atau non tes. Analisis data yang diperoleh meliputi analisis kemampuan berpikir kritis peserta didik, analisis lembar observasi kegiatan aktivitas guru dan lembar observasi kegiatan aktivtitas peserta didik.

\section{C.Hasil Penelitian dan Pembahasan}

\section{Hasil Penelitian}

\section{a. Keterampilan Berpikir Kritis}

Selama proses pembelajaran menggunakan model PBL pada tema 7 di kelas V MIM 01 Sambong dilakukan tes uraian kemampuan berpikir kritis berjumlah 5 soal, pada setiap pertemuan di siklus I. Berikut indikator keterampilan berpikir kritis disajikan dalam tabel 1 dan rekapitulasi hasil tes kemampuan berpikir kritis siklus I disajikan dalam tabel 2.

\section{Tabel 1 Indikator Keterampilan Berpikir} Kritis

Tabel 2 Rekapitulasi Hasil Tes Keterampilan Berpikir Kritis Siklus I

\begin{tabular}{|c|c|c|c|c|c|}
\hline \multirow{2}{*}{ | } & \multicolumn{2}{|c|}{ Skor } & \multirow{2}{*}{$\uparrow$} & \multirow{2}{*}{$\downarrow$} & \multirow{2}{*}{$\Sigma$} \\
\hline & P1 & P2 & & & \\
\hline 1 & 3,27 & 3,13 & - & $-0,14$ & 6,6 \\
\hline 2 & 3,22 & 3,09 & - & $-0,13$ & $6,31 \quad 3,15$ \\
\hline 3 & 2,77 & 3,04 & $+0,27$ & - & $5,81 \quad 2,9$ \\
\hline 4 & 3,09 & 3,45 & $+0,36$ & - & $6,54 \quad 3.27$ \\
\hline 5 & 2,18 & 3,36 & $+1,18$ & & $5,54 \quad 2,77$ \\
\hline$\Sigma$ & 14,53 & 16,07 & $+1,81$ & $-0,27$ & 30,6 \\
\hline$\overline{\bar{X}}$ & 2,89 & 3,2 & & & 3,06 \\
\hline K & $\mathrm{KB}$ & $\mathrm{KB}$ & & & KB \\
\hline
\end{tabular}

\section{Keterangan}

I : Indikator

P1 : Pembelajaran 1

P2 : Pembelajaran 2

$\uparrow \quad$ : Kenaikan

$\downarrow \quad$ : Penurunan

$\sum \quad$ : Jumlah

$\overline{\bar{X}} \quad$ : Rata-rata

K : Kriteria 
KB : Kurang Baik

Berdasarkan tabel 2 di atas, siklus I pertemuan 1 peserta didik mendapatkan rata-rata 2,89 dengan kriteria kurang baik hal ini tentu belum mencapai indikator keberhasilan penelitian. Sedangkan pada siklus I pertemuan 2 mendapatkan skor ratarata 3,2 dengan kriteria kurang baik. Rata-rata siklus I dari pertemuan 1 dan pertemuan 2 memperoleh skor rata-rata 3,06 dengan menunjukan kriteria kurang baik. Temuan pada siklus I setiap pertemuan menunjukan adanya peningkatan dan penurunan setiap indikator, dibuktikan dengan indiaktor 1 mengalami penurunan yaitu 0,14 . Indikator 2 mengalami penurunan skor 0,13 . Indikator 3 mengalami peningkatan skor 0,27. Indikator 4 mengalami peningkatan skor sebesar 0,36. Indikator 5 mengalami peningkatan sebesar 1,18. Pencapain dari hasil siklus 1 dari pertemuan 1 dan pertemuan 2 belum mencapai indikator keberhasilan. Indikator keberhasilan pada penelitian ini yaitu mencapai skor $3,4 \mathrm{~s} / \mathrm{d} 4,2$ dengan kriteria baik.

Selama proses pembelajaran menggunakan model PBL pada tema 7 di kelas V MIM 01 Sambong dilakukan tes uraian kemampuan berpikir kritis berjumlah 5 soal, pada setiap pertemuan di siklus II. Berikut rekapitulasi hasil tes kemampuan berpikir kritis siklus II.

Tabel 3 Rekapitulasi Hasil Keterampilan Berpikir Kritis Siklus II

\begin{tabular}{|c|c|c|c|c|c|c|}
\hline \multirow{2}{*}{ I } & \multicolumn{2}{|c|}{ Skor } & \multirow[b]{2}{*}{$\uparrow$} & \multirow{2}{*}{$\downarrow$} & \multirow{2}{*}{$\Sigma$} & \multirow{2}{*}{$\bar{X}$} \\
\hline & P1 & P2 & & & & \\
\hline 1 & 3,54 & 4,31 & $+0,77$ & - & 7,85 & 3,9 \\
\hline 2 & 3,77 & 3,63 & - & $-0,14$ & 7,4 & 3,7 \\
\hline 3 & 3,54 & 3,95 & $+0,41$ & - & 7,4 & 3,7 \\
\hline 4 & 3,72 & 3,72 & - & - & 7,4 & 3.7 \\
\hline 5 & 3,77 & 3,86 & $+0,09$ & & 7,63 & 3,8 \\
\hline$\Sigma$ & 18,34 & 19,47 & $+1,27$ & $-0,14$ & & 81 \\
\hline$\overline{\bar{X}}$ & 3,6 & 3,8 & & & & \\
\hline K & Baik & Baik & & & & ik \\
\hline
\end{tabular}

\section{Keterangan:}

I : Indikator

P1 : Pembelajaran 1

P2 : Pembelajaran 2

$\begin{array}{ll}\uparrow & : \text { Kenaikan } \\ \downarrow & \text { : Penurunan } \\ \sum_{\bar{X}} & : \text { Jumlah } \\ \mathrm{K} & \text { : Rata-rata } \\ & \text { Kriteria }\end{array}$

Berdasarkan tabel 3 di atas, siklus II pertemuan 1 peserta didik mendapatkan rata-rata 3,6 dengan kriteria baik hal ini tentu mencapai indikator keberhasilan penelitian. Sedangkan pada siklus I pertemuan 2 mendapatkan skor rata-rata 3,8 dengan kriteria baik. Rata-rata siklus II dari pertemuan 1 dan pertemuan 2 memperoleh skor rata-rata 3,78 dengan menunjukan kriteria baik. Temuan pada siklus II setiap pertemuan menunjukan adanya peningkatan, penurunan dan tetap di setiap indikator, dibuktikan dengan 
indiaktor 1 mengalami kenaikan yaitu 0,77. Indikator 2 mengalami penurunan skor 0,14 . Indikator 3 mengalami peningkatan skor 0,41. Indikator 4 tidak ada peningkatan maupun penurunan. Indikator 5 mengalami peningkatan sebesar 0,09. Pencapain dari hasil siklus II dari pertemuan 1 dan pertemuan 2 mencapai indikator keberhasilan. Indikator keberhasilan pada penelitian ini yaitu mencapai skor $3,4 \mathrm{~s} / \mathrm{d} 4,2$ dengan kriteria baik.

\section{b. Kemandirian Belajar}

Selama proses pembelajaran menggunakan model PBL pada tema 7 di kelas V MIM 01 Sambong dilakukan pemberian angket sikap kemandirian belajar peserta didik, berdasarkan indikator kemandirian belajar yaitu: 1) Bertanggung Jawab, 2) Mempunyai Inisiatif, 3) Tidak Bergantung dengan orang lain, yang terdiri dari 14 butir pernyataan pada setiap siklus. Berikut rekapitulasi hasil Kemandirian Belajar pada setiap siklus.

Tabel 4 Rekapitulasi Hasil Kemandirian Belajar pada Setiap Siklus

\begin{tabular}{llcc}
\hline I & PERNYATAAN & S1 & S2 \\
\hline 1 & $\begin{array}{l}\text { Saya tepat waktu dalam } \\
\text { menyelesaikan tugas }\end{array}$ & 63 & 80 \\
& $\begin{array}{l}\text { Saya tidak serius dalam } \\
\text { mengerjakan tugas }\end{array}$ & 70 & 106 \\
\hline
\end{tabular}

\begin{tabular}{|c|c|c|c|}
\hline \multirow{3}{*}{$I$} & PERNYATAAN & S1 & S2 \\
\hline & $\begin{array}{l}\text { Saya tidak bersungguh- } \\
\text { sungguh dalam mengikuti } \\
\text { pelajaran }\end{array}$ & 80 & 90 \\
\hline & $\begin{array}{ll}\text { Saya turut serta } & \text { dalam } \\
\text { melaksanakan } & \text { tugas } \\
\text { kelompok } & \\
\end{array}$ & 88 & 80 \\
\hline \multirow[t]{6}{*}{2} & $\begin{array}{lr}\text { Ketika saya } & \text { belum } \\
\text { memahami } & \text { cara } \\
\text { menyelesaikan } & \text { tugas, } \\
\text { saya mencari jawaban } \\
\text { melalui buku atau internet }\end{array}$ & 51 & 82 \\
\hline & $\begin{array}{lrr}\text { Ketika saya } & \text { belum } \\
\text { memahami } & \text { yang } & \text { guru } \\
\text { ajarkan, } & & \text { saya } \\
\text { mengajukan } & \text { pertanyaan } \\
\text { kepada guru } & & \end{array}$ & 71 & 74 \\
\hline & $\begin{array}{ll}\begin{array}{l}\text { Ketika berdiskusi, saya } \\
\text { tidak }\end{array} & \text { mengusulkan } \\
\text { pendapat } & \end{array}$ & 78 & 81 \\
\hline & $\begin{array}{lr}\text { Saya } & \text { menanggapi } \\
\text { jawaban teman ketika } \\
\text { berdiskusi }\end{array}$ & 91 & 80 \\
\hline & $\begin{array}{ll}\text { Ketika terdapat hal yang } \\
\text { baru, saya } & \text { tidak } \\
\text { penasaran dengan hal } \\
\text { tersebut }\end{array}$ & 67 & 75 \\
\hline & $\begin{array}{l}\text { Saya tidak menjawab } \\
\text { pertanyaan guru, apabila } \\
\text { guru bertanya }\end{array}$ & 81 & 85 \\
\hline \multirow[t]{6}{*}{3} & $\begin{array}{lcc}\text { Saya belajar } & \text { bukan } \\
\text { kemauan sendiri } & \\
\end{array}$ & 77 & 79 \\
\hline & $\begin{array}{l}\text { Saya belajar dengan cara } \\
\text { saya }\end{array}$ & 56 & 70 \\
\hline & $\begin{array}{l}\text { Saya mengerjakan soal } \\
\text { dengan bantuan orang } \\
\text { lain }\end{array}$ & 64 & 75 \\
\hline & $\begin{array}{l}\text { Saya mengatasi sendiri } \\
\text { kesulitan yang saya alami } \\
\text { dalam belajar }\end{array}$ & 64 & 76 \\
\hline & Rata-rata & 3,2 & 3,67 \\
\hline & Kriteria & KB & B \\
\hline
\end{tabular}

\section{Keterangan:}

I: : Indikator

S1 : Siklus 1

S2 : Siklus 2

KB : Kurang Baik

B : Baik

Berdasarkan tabel 4 rekapitulasi kemandirian belajar peserta didik, siklus 1 mendapatkan skor rata-rata 
3,2 dengan kriteria kurang baik sedangkan siklus 2 memperoleh skor 3,67 dengan kriteria baik. Temuan pada kemandirian belajar peserta ddik di kelas V MIM 01 Sambong mengalami peningkatan setiap siklus. Kenaikan yang signifikan pada indikator 1 yaitu bertanggung jawab pada siklus 1 memperoleh 70 sedangkan siklus 2 memperoleh 106. Indikator yang mengalami penurunan pada indikator 2 yaitu mempunyai inisiatif pada pada siklus 1 mempeoleh 91 pada siklus 2 memperoleh 80. Temuan yang lainnya yaitu di kemandirian belajar peserta didik tersebut masih ada yang belum lancar membaca dan menulis sehingga proses pebelajaran menjadi tertinggal.

\section{Pembahasan}

Pada penelitian tindakan kelas (PTK) untuk meningkatkan keterampilan berpikir kritis dan kemandirian belajar. Tes keerampilan berpikir kritis disesuaikan dengan indikator keterampilan bepikir kritis . Susanto (2015:125) indikator berpikir kritis yaitu 1) memberikan penjelasan sederhana, 2) membangun keterampilam dasar, 3) membuat intervensi atau menyimpulkan, 4) memberikan penjelasan lebih lanjut, 5) mengatur strategi dan taktik. Hasil skor rata-rata kemampuan berpikir kritis setiap indikator siklus I dan siklus II disajikan dalam gambar diagram batang berikut:

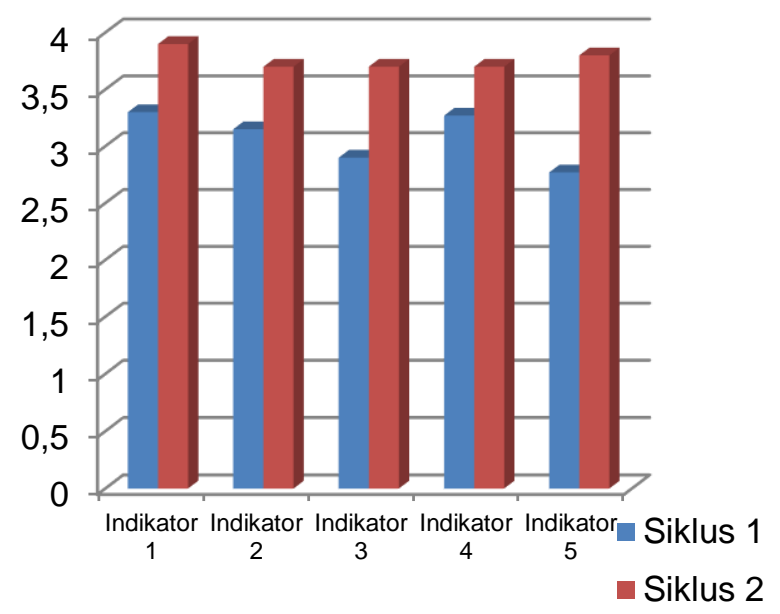

Gambar 1 Hasil Skor Rata-rata Keterampilan Berpikir Kritis Setiap Indikator pada siklus I dan II

Temuan dalam penelitian ini ditunjukkan dengan peningkatan hasil tes keterampilan berpikir kritis setiap indikator berpikir kritis, yaitu indikator 1) memberikan penjelasan sederhana, pada siklus I peserta didik memperoleh skor rata-rata 3,3 kriteria kurang baik sedangkan siklus II memperoleh skor rata-rata 3,9 kriteria baik. Indikator 2) membangun keterampilan dasar, pada siklus I peserta didik memperoleh skor ratarata 3,15 kriteria baik, sedangkan siklus II memperoleh skor rata-rata 3,7 dengan kriteria baik. Indikator 3) 
membuat intervensi atau menyimpulkan, pada siklus I peserta didik memperoleh skor rata-rata 2,9 dengan kriteria kurang baik sedangkan siklus II memperoleh skor rata-rata 3,7 dengan kriteria baik. Indikator 4) memberikan penjelasan lebih lanjut, pada siklus I peserta didik memperoleh skor rata-rata 3,27 dengan kriteria kurang baik sedangkan siklus II memperoleh skor rata-rata 3,7 dengan kriteria baik. Indikator 5) mengatur strategi dan taktik, pada siklus I peserta didik memperoleh rata-rata 2,77 dengan kriteria kurang baik sedangkan siklus II memperoleh skor rata-rata 3,8 kriteria baik. Pada keterampilan berpikir kritis ini mencapai indikator keberhasilan dalam penelitan. Sedangkan kemandirian belajar peserta didik menurut Rahmawati (Putri, 2018: 7) kemandirian belajar merupakan tingkah laku yang benar sebagai hasil perubahan pada diri individu atas pengalaman dan latihan tanpa tergantung pada orang lain. Indikator kemandirian belajar menurut Maga (2016: 39), yaitu: 1) Mampu menyelesaikan tugas, 2) Tanggung jawab, 3) Mampu mengatasi masalah, 4) Percaya pada kemampuan sendiri.
Berikut hasil kemandirian belajar tiap siklus:

Tabel 5 Hasil Rata-rata Kemandirian Belajar tiap Siklus

\begin{tabular}{|c|c|c|c|}
\hline No & Indikator & S1 & S2 \\
\hline 1 & Bertanggung jawab & \multirow{3}{*}{3,2} & \multirow{3}{*}{3,67} \\
\hline 2 & Mempunyai inisiatif & & \\
\hline 3 & $\begin{array}{l}\text { Tidak bergantung } \\
\text { dengan orang lain }\end{array}$ & & \\
\hline
\end{tabular}

\section{Keterangan:}

S1 : Siklus 1

S2 : Siklus 2

Kemandiiran belajar pada siklus 1 memperoleh skor rata-rata 3,2 belum mencapai indikator keberhasilan, sedangkan siklus 2 memperoleh skor rata-rata 3,67, pada siklus 2 ini mencapai indikator keberhasilan dengan krtiteria baik. Model pembelajaran PBL memberikan dampak yang positif terhadap pembelajaran untuk meningkaykan keterampilan berpikir kritis dan kemandiian belajar peserta didik. Model pembelajaran PBL adalah pembelajaran yang menitik beratkan kepada peserta didik sebagai pembelajar serta terhadap permasalahan yang otentik atau relevan yang akan dipecahkan dengan menggunakan seluruh pengetahuan yang dimilikinya atau dari sumber-sumber lainnya Lidnillah (Fauzia, 2018: 42). Sedangkan menurut Shoimin (Hardono, 2017: 2) model pembelajaran PBL adalah 
model pembelajaran yang dapat melatih dan mengembangkan kemampuan untuk menyelesaikan masalah yang berorientasi pada masalah autentik dari kehidupan aktual siswa. Kemampuan bepikir kritis mempunyai peranan penting bagi peserta didik yang harus dikembangkan supaya peserta didik lebih mudah memahami konsep dan memiliki sudut pandang yang berbeda dalam mengatasi permasalahan. Beberapa pertimbangan pentingnya berpikir kritis di lembaga pendidikan juga di sampaikan oleh Tilaar (2011: 17), yaitu: 1) mengembangkan berpikir kritis dalam pendidikan berarti telah memberikan penghargaan kepada peserta didik sebagai pribadi, 2) berpikir kritis adalah tujuan yang ideal dalam pendidikan karena menyiapkan peserta didik untuk kehidupan di masa yang akan datang, 3) pengembangan berpikir kritis dalam proses pendidikan yaitu suatu cita-cita yang ingin dicapai, 4) berpikir kritis merupakan suatu hal yang sangat dibutuhkan dalam kehidupan berbangsa dan bernegara. Berdasarkan pendapat tersebut dapat disimpulkan bahwa berpikir kritis sangat penting bagi peserta didik supaya menjadi seorang yang mandiri dalam menentukan solusi untuk memecahkan masalah sesuai dengan pola pemikiran dan pengetahuang yang dimiliki setiap peserta didik. Kemampuan berpikir kritis pada saat ini untuk mempersiapan peserta didik untuk kehidupan di masa yang akan datang dan di kehidupan abad 21 .

\section{Kesimpulan}

Berdasarkan hasil penelitian yang telah dilakukan selama 2 siklus dalam meningkatkan kemampuan berpikir kritis peserta didik menggunakan model Problem Based Learning di kelas V MIM 01 Sambong menunjukan hasil sesuai dengan indikator keberhasilan yaitu $70 \%$ peserta didik yang memenuhi kemampuan berpikir kritis dan kemandirian belajar mencapai kriteria baik yaitu $3,4 \mathrm{~s} / \mathrm{d} 4,2$. Pada siklus 1 keterampilan berpikir kritis memperoleh rata-rata 3,06 dengan kriteria kurang baik dan pada siklus II memperoleh rata-rata 3,78 dengan kritiria baik. Kemandirian belajar pada penelitian ini siklus I memperoleh 3,2 kriteria kurang baik dan siklus II memperoleh 3,67 dengan krieria baik. Berdasarkan hasil tersebut membuktikan bahwa model PBL dapat meningkatkan keterampilan 
berpikir kritis dan kemandirian peserta didik.

\begin{tabular}{lrr}
\multicolumn{2}{c}{ Beberapa saran yang perlu } \\
diterapkan dalam \\
pembelajaran di kelas yaitu guru
\end{tabular}
harus memperhatikan potensi yang harus dikembangkan peserta didik di dalam abad 21, dalam menggunakan model pembelaajran harus sesuai dengan RPP yang telah disusun. Kemudian, guru dapat mengimplentasikan penggunaan model PBL dapat dengan berbantu media pembelajaran supaya digunakan dalam pembelajaran yang lainnya dan dapat mengaitkan dengan kehidupan sehari-hari peserta didik supaya dapat bermakna. Hasil penelitian ini dapat dikembangkan lagi oleh pembaca. Hal tersebut dilakukan dalam rangka mencari solusi terbaik dalam pembelajaran tematik dalam kurikulum 2013 supaya dapat lebih baik lagi.

\section{DAFTAR PUSTAKA}

Arikunto, S. (2010). Penelitian Tindakan Kelas. Yogyakarta: Aditya Media

Fauzia, H. A. (2018). Penerapan Model Pembelajaran Problem Based Learning Untuk Meningkatkan Hasil Belajar Matematika SD. Primary: Jurnal
Pendidikan Guru

Sekolah

Dasar, 7(1), 40-47

Hardono, F. P., Istiyati, S., \& Atmojo, I. R. W. (2017). Penerapan Model Pembelajaran Problem Based Learning (PBL) untuk Meningkatkan Keterampilan Proses IPA pada Siswa Sekolah Dasar. Didaktika Dwija Indria, 1-8. Indriyani, D., Mawardi, M., \& Wardani, K. W. (2019). Peningkatan Keterampilan Berpikir Kritis melalui Model Inkuiri Berbantuan Media Konkret pada Siswa Kelas 5 SD Negeri Mangunsari 05 Tahun Pelajaran 2018/2019. Jurnal Basicedu, 3(1), 27-32.

Maga, Y. O. E. L. (2016). Peningkatan Kemandirian dan Hasil Belajar Matematika Melalui Strategi Metakognitif Berbasis Tutor Sebaya Bagi Siswa Kelas V SD YPK Persiapan Kampung ANNY. Jurnal Surya LPMP Provinsi Papua Barat, 14, 37-42.

Nugraha, W. S. (2016). Peningkatan Kemampuan Berpikir Kritis Dan Penguasaan Konsep Ipa Siswa Sd Dengan Menggunakan Model Problem Based Learning (Doctoral dissertation, Universitas Pendidikan Indonesia).

Putri, F. A., \& Wahyono, B. (2018). Pengaruh Pemanfaatan Internet Sebagai Sumber Belajar dan Kemandirian Belajar Terhadap Prestasi Belajar Mahasiswa Pendidikan Ekonomi FKIP UNS Angkatan Tahun 2017. Jurnal Pendidikan Bisnis dan Ekonomi, 4(2). 
Suid \& Syafrina, A. (2017). Analisis Kemandirian Siswa Dalam Proses Pembelajaran Di Kelas III SD Negeri 1 Banda Aceh.Jurnal Pesona Dasar, 1(5), 70-81.

Susanto, A. (2015). Teori Belajar dan Pembelajaran di Sekolah Dasar. Jakarta: Kencana

Susilowati, A. (2018). Pengaruh PBL terhadap Kemandirian Belajar Siswa SD. Indonesian Journal of Primary Education,2(1), 72-77.

Tilaar, dkk. (2011). Pendagogik Kritis. Jakarta: Rineka Cipta. 